J. Reprod. Fert. (1968) 17, 119-123

\title{
EVIDENCE OF PRECOCIOUS PUBERTY IN THE IMMATURE FEMALE RHESUS MONKEY (MACACA $M U L A T T A)$ TREATED WITH PREGNANT MARE'S SERUM GONADOTROPHIN
}

\author{
MUHAMMAD ARSLAN, RIGHARD G. WOLF, ROLAND K. MEYER \\ AND M. R. N. PRASAD* \\ Departments of Zoology and Physiology, \\ University of Wisconsin, Madison, Wisconsin
}

(Received 5th October 1967, revised 28th November 1967)

\begin{abstract}
Summary. Twelve immature female monkeys were treated with varying amounts of pregnant mare's serum gonadotrophin (PMSG). Seven of these monkeys responded to PMSG treatment as shown by sex skin development, ovarian enlargement and withdrawal bleeding. These animals reached menarche between 23 and 26 months of age, almost 1 year earlier than untreated control monkeys. Five other animals did not show an initial response to PMSG treatment and attained puberty simultaneously with the untreated animals. It is suggested that increased production of oestrogen by the PMSG-stimulated ovaries may affect the hypothalamo-hypophysial axis in such a way that puberty is accelerated.
\end{abstract}

\section{INTRODUCTION}

Exogenous administration of gonadotrophic as well as gonadal hormones is known to affect the processes leading to normal puberty (Everett, 1961; Ramirez \& Sawyer, 1965; Strauss, 1964). In a study originally designed to find an effective regimen for inducing ovulation in immature monkeys with PMSG, it was observed that evidence of puberty appeared much earlier in treated animals than in untreated ones or in those which failed to show an initial response to PMSG administration. Puberty is defined in accordance with Hartman (1932) as the time of the first spontaneous menstruation or menarche.

\section{MATERIALS AND METHODS}

The present study is based on sixteen immature female monkeys received in our colony from India in April 1965. The animals were acclimatized to colony conditions for at least 3 months before treatment. The age of the animals was calculated using a dental formula described by Haigh \& Scott (1965). Dentition has been considered a relatively more accurate factor than body weight in determining the age of the immature monkey. Using the dental formula the

\footnotetext{
* Present address: Department of Zoology, University of Delhi, India.
} 
estimated age of the animals may involve an error of \pm 2 months. The body weights of the animals at the beginning of the experiments ranged from $2 \cdot 1$ to $2 \cdot 6 \mathrm{~kg}$.

The experimental animals were treated with varying amounts of PMSG (Antex Leo) as described in Table 1. The colour of the sex skin was recorded

TABLE 1

DOSE REGIMEN OF PMSG TREATMENT TO IMMATURE MONKEYS

\begin{tabular}{|c|c|c|c|c|c|}
\hline \multirow{2}{*}{$\begin{array}{c}\text { Monkey } \\
\text { no. }\end{array}$} & \multicolumn{5}{|c|}{ Injection (i.u. PMSG) } \\
\hline & $I$ & $I I$ & $I I I$ & $I V$ & $V$ \\
\hline $\begin{array}{r}1 \\
2 \\
3 \\
4 \\
5 \\
6 \\
7 \\
8 \\
9 \\
10 \\
11 \\
15\end{array}$ & $\begin{array}{rr}600 & (1 \\
125 & (1 \\
50 & (1 \\
250 & (1 \\
100 & (1 \\
250 & (1 \\
100 & (1 \\
600 & (1 \\
600 & (1 \\
50 & (1 \\
1200 & (1 \\
1200 & (1\end{array}$ & \begin{tabular}{rc}
200 & $(4)$ \\
75 & $(4)$ \\
50 & $(4)$ \\
150 & $(4)$ \\
100 & $(4)$ \\
150 & $(4)$ \\
100 & $(4)$ \\
600 & $(7)$ \\
600 & $(7)$ \\
50 & $(2)$ \\
- & \multicolumn{2}{c}{} \\
-
\end{tabular} & 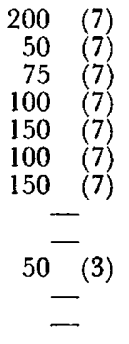 & $\begin{array}{rc}200 & (10) \\
50 & (10) \\
125 & (10) \\
100 & (10) \\
250 & (10) \\
100 & (10) \\
250 \quad(10) \\
= \\
50- \\
5 \\
-\end{array}$ & $\begin{array}{c}= \\
= \\
= \\
= \\
= \\
{ }^{1200}= \\
=\end{array}$ \\
\hline
\end{tabular}

Numbers in parentheses indicate day of injection. Day of the first injection is considered as Day 1.

by making use of a graded series of oil colour charts. The colours were matched to the sex skin and were given values from \pm to ++++ . All animals were checked daily for menstruation, and any uterine bleeding recorded on 2 or more consecutive days was regarded as menstruation.

Laparotomies were performed under ether anaesthesia. At the time of laparotomy the ovaries were measured and examined in situ by transillumination to note the approximate number and size of follicles. As a rule, the experimental animals were laparotomized before the initiation of PMSG administration and again within 7 to 15 days after the first injection, irrespective of whether the animal exhibited sex skin stimulation or not. The animals also underwent laparotomy at the time of spontaneous sexual stimulation before menarche.

\section{RESULTS}

The results of this investigation are summarized in Table 2.

\section{PMSG-treated monkeys}

These animals may be divided into two groups according to their response to PMSG treatment.

Group $I(1,4,7,8,9,10$ and 11). These animals showed an immediate response to PMSG treatment as indicated by considerable development of the sex skin and increase in intensity of its colour, and swelling of the vulvar and perineal tissues. The animals laparotomized at this stage had enlarged ovaries, an increased number and size of follicles and an occasional cystic follicle. In no 
instance was ovulation or the formation of a corpus luteum evident on direct observation of the ovaries. The waning of sex skin swelling and colour was invariably followed by macroscopic uterine bleeding which lasted for at least 3 consecutive days. In all these animals spontaneous menstruation was recorded at a time much earlier than in untreated animals. This spontaneous menstruation may be regarded as the menarche. The animals then exhibited irregular cycles-a phenomenon which is characteristic of adolescent monkeys. In this group of animals the average length of the first 'cycle' was 76 days (range 39 to 141 days).

TABLE 2

PRECOGIOUS PUBERTY IN PMSG-TREATED IMMATURE MONKEYS

\begin{tabular}{|c|c|c|c|c|c|c|}
\hline $\begin{array}{c}\text { Monkey } \\
\text { no. }\end{array}$ & $\begin{array}{c}\text { Estimated } \\
\text { age at start } \\
\text { of treatment } \\
\text { (months) }\end{array}$ & $\begin{array}{c}\text { Total dose } \\
\text { of PMSG } \\
\quad(i . u .)\end{array}$ & $\begin{array}{l}\text { Approx. } \\
\text { duration of } \\
\text { response* } \\
(\text { days })\end{array}$ & $\begin{array}{c}\text { Onset and } \\
\text { duration of } \\
\text { withdrawal } \\
\text { bleeding } \\
\text { (days) }\end{array}$ & $\begin{array}{c}\text { Interval between } \\
\text { last injection and } \\
\text { beginning of with- } \\
\text { drawal bleeding } \\
\text { (days) }\end{array}$ & $\begin{array}{c}\text { Age at } \\
\text { menarche } \\
\text { (months) }\end{array}$ \\
\hline $\begin{array}{r}1 \\
4 \\
7 \\
8 \\
9 \\
10 \\
11\end{array}$ & $\begin{array}{l}21 \\
17 \\
18 \\
18 \\
18 \\
22 \\
16\end{array}$ & $\begin{array}{r}1200 \\
600 \\
600 \\
1200 \\
1200 \\
1400 \\
1200\end{array}$ & $\begin{array}{c}5-17 \dagger \\
6-16 \\
11-17 \\
4-14 \\
4-12 \\
6-16 \\
5-12\end{array}$ & $\begin{array}{l}18-26 \dagger \\
22-26 \\
19-21 \\
19-23 \\
16-20 \\
20-24 \\
13-17\end{array}$ & $\begin{array}{r}8 \\
12 \\
9 \\
12 \\
9 \\
15 \\
12\end{array}$ & $\begin{array}{l}24 \\
26 \\
25 \\
25 \\
26 \\
24 \\
23\end{array}$ \\
\hline $\begin{array}{r}2 \\
3 \\
5 \\
6 \\
15\end{array}$ & $\begin{array}{l}19 \\
16 \\
23 \\
14 \\
21\end{array}$ & $\begin{array}{r}300 \\
300 \\
600 \\
600 \\
1200\end{array}$ & $\begin{array}{l}\text { No response } \\
\text { No response } \\
\text { No response } \\
\text { No response } \\
\text { No response }\end{array}$ & $\begin{array}{l}E \\
E \\
=\end{array}$ & $\begin{array}{l}- \\
\bar{E} \\
\overline{-}\end{array}$ & $\begin{array}{l}43 \\
31 \\
34 \\
\frac{39}{}\end{array}$ \\
\hline $\begin{array}{l}15 \\
18 \\
19 \\
23 \\
24\end{array}$ & $\begin{array}{l}21 \\
\text { E } \\
-\end{array}$ & $\begin{array}{l}1200 \\
- \\
-\end{array}$ & $\begin{array}{c}\text { No response } \\
= \\
= \\
=\end{array}$ & $\begin{array}{l}- \\
\overline{-} \\
=\end{array}$ & $\begin{array}{l}- \\
\overline{-}\end{array}$ & $\begin{array}{l}39 \\
-73 \\
36 \\
39\end{array}$ \\
\hline
\end{tabular}

* Sex skin development and enlargement of ovaries and follicles.

$\uparrow$ Day of first injection is considered as Day 1.

$\$$ No menarche at 36 months.

if No menarche at 45 months.

The menarche and subsequent menstruations were preceded by characteristic reddening of the sex skin and swelling of the genitalia. Periodic laparotomies of these monkeys after the menarche had occurred revealed that, in all except one (No. 10), the cycles were anovulatory. In Monkey 10, however, the ovary had a corpus luteum when examined during the cycle subsequent to menarche.

Group II (2, 3, 5, 6 and 15). These animals did not show a response to PMSG treatment. No changes occurred in the sex skin and no withdrawal bleeding could be observed after PMSG treatment. Post-treatment laparotomies revealed ovaries comparable in size and follicular development to those observed in control animals. The absence of responsiveness to PMSG might have been due to the relatively small dosages (300 i.u.) administered to Monkeys 2 and 3. However, the reason for refractoriness of Monkeys 5, 6 and 15 to PMSG is not apparent. Menarche was reached considerably later in Monkeys 2, 3,5 and 15 than in those which showed an immediate response to PMSG treatment. In Monkey 6 
menarche had not occurred at the age of 36 months. This animal was subsequently used for a different experiment.

\section{Untreated monkeys $(18,19,23$ and 24)}

In three of these animals the first menstruation was observed between the ages of 33 and 39 months. No menstruation was recorded in Monkey 18 up to the age of 45 months. The average length of the first cycle in Monkeys 19, 23 and 24 was 83 days (range 78 to 87 days).

\section{DISCUSSION}

The usual age at which the first menstruation occurs in the monkey is 3 years (Asdell, 1964), although at the Yale Obstetric Monkey Colony menarche is reported to have occurred at about 2 years in normal females (van Wagenen 1949). In our study, the first menstruation in untreated animals occurred between 33 and 39 months of age. However, animals which showed an initial response to PMSG treatment reached the menarche between the ages of 23 and 26 months. Equally significant is the observation that those monkeys which apparently did not show a treatment-induced response reached menarche at an age comparable to that of untreated control animals.

That the administration of PMSG to immature animals may cause an alteration in the normal chronology of puberty has been indicated by Strauss (1964) who reported a precocity of regular oestrous cycles in PMSG-treated immature female rats. In 30-day-old rats treated with PMSG the first regular oestrus was advanced by 2.5 days over that of untreated rats.

The fact that the sex skin was greatly stimulated in the seven PMSG-sensitive monkeys may be regarded as positive, although indirect, evidence of oestrogen production by the ovaries. The organizing effects of steroids on the immature hypothalamo-hypophysial axis have been emphasized by numerous workers (Everett, 1961; Ramirez \& Sawyer, 1965). Furthermore, Engle (1931) and Hohlweg (1934) have shown that short-term injections of oestrogen caused precocious puberty in intact immature rats and mice. Moreover, steroids other than oestrogen may also affect the time of puberty. Van Wagenen (1949) demonstrated sexual precocity in immature female monkeys as a consequence of testosterone administration. It may be postulated, therefore, that the PMSGstimulated oestrogen production in these immature monkeys might have produced a permanent alteration, lasting after the treatment-induced response. Further support for such a postulate comes from the observation that those PMSG-treated monkeys which apparently did not show sufficient PMSG-induced production of oestrogen reached puberty significantly later than the ones which responded to PMSG treatment. In the present investigation, however, no attempt was made to obtain direct evidence for the postulated explanation of the difference between the two experimental groups.

The possibility was explored that PMSG induced the formation of anti-PMSG gonadotrophin and that following cessation of treatment and the subsequent decline in anti-gonadotrophin titre a hypersecretion of endogenous gonadotrophin occurred which, in turn, resulted in the observed precocity. Kupperman, 
Meyer \& Finerty (1942) demonstrated a hypersecretion of gonadotrophin by the pituitary gland in the immature rat following treatment with a non-specific anti-gonadotrophic serum. On withdrawal of this anti-gonadotrophic treatment, the hypersecretion resulted in a precocious gonadal development. Although a specific anti-PMSG gonadotrophin was developed by us in the monkey, it did not cross-react with monkey pituitary gonadotrophin.

In conclusion, it is suggested that the sexual precocity observed in PMSGtreated immature female monkeys is due to an increased oestrogen production by the ovaries. The oestrogen in turn may affect the hypothalamo-hypophysial axis, thus bringing about an alteration of the normal processes leading to puberty.

\section{ACKNOWLEDGMENT}

This investigation was supported in part by Ford Foundation Grant No. 63-505.

\section{REFERENCES}

Aspelz, S. A. (1964) Patterns of mammalian reproduction, 2nd edn, p. 143. Constable, London.

ENGLE, E. T. (1931) The pituitary gonadal relationship and the problem of precocious sexual maturity. Endocrinology, 15, 405.

EveretT, J. W. (1961) The mammalian female reproductive cycle and its controlling mechanisms. In: Sex and Internal Secretions, 3rd edn. Ed. W. C. Young. Williams \& Wilkins, Baltimore.

HAigh, V. M. \& ScotT, A. (1965) Some radiological and other factors for assessing age in the rhesus monkey using animals of known age. Lab. Anim. Care, 15, 57.

Hartman, C. G. (1932) Studies on the reproduction of the monkey Macacus (Pithecus), with special reference to menstruation and pregnancy. Contr. Embryol. 23, 1.

Hohlweg, W. (1934) Veränderungen des Hypophysenvorderlappens und des Ovariums nach Behandlungen mit grossen Dosen von Follikelhormon. Klin. Wschr. 13, 92.

Kupperman, H. S., Meyer, R. K. \& Finerty, J. C. (1942) Precocious gonadal development occurring in immature rats following a short time treatment with anti-gonadotropic serum. Am. F. Physiol. 136, 293.

Ramirez, V. D. \& SAWYeR, C. H. (1965) Advancement of puberty in the female rat by estrogen. Endocrinology, 76, 1158.

Strauss, W. F. (1964) Neural timing of ovulation in immature rats treated with gonadotrophin. Ph.D. thesis, University of Wisconsin.

VAN WAGENEN, G. (1949) Accelerated growth with sexual precocity in female monkeys receiving testosterone propionate. Endocrinology, 45, 544. 